\title{
Advances in the ecology of freshwater mysids
}

\author{
Idea and coordination: Lars G. Rudstam, Ora E. Johannsson
}

\section{CONTENTS}

Rudstam LG, Johannsson OE

Introduction

$246-248$

Johannsson OE, Bowen KL, Arts MT, Smith RW

Field assessment of condition indices (nucleic acid and protein) in Mysis diluviana
Boscarino BT, Rudstam LG, Eillenberger JJ, O'Gorman R Importance of light, temperature, zooplankton and fish in predicting the nighttime vertical distribution of Mysis diluviana ......................................... 263-279

Whall JD, Lasenby DC

Differences in the trophic role of Mysis diluviana in two intermontane lakes 281-292

Koksvik JI, Reinertsen H, Koksvik J

Plankton development in Lake Jonsvatn, Norway, after introduction of Mysis relicta: a long-term study ........... 293-304

\section{Introduction}

\author{
Lars G. Rudstam ${ }^{1, *}$, Ora E. Johannsson ${ }^{2}$ \\ ${ }^{1}$ Cornell Biological Field Station, Department of Natural Resources, Cornell University, Bridgeport, New York 13030, USA \\ ${ }^{2}$ Fisheries and Oceans, Canada, Great Lakes Laboratory for Fisheries and Aquatic Sciences, 867 Lakeshore Rd, Burlington, \\ Ontario L7R 4A6, Canada
}

\begin{abstract}
Mysids can be considered the krill of lakes. These crustaceans are relatively small $(<30 \mathrm{~mm})$, omnivorous, perform extensive vertical migrations, are a major food source for fishes, and can be the dominant species by mass in lakes. This Theme Section comprises 4 papers that represent significant advances in the study of these ecologically important animals, including techniques that were not available 20 years ago, such as DNA:RNA:protein ratios, fatty acids and stable isotopes as growth indicators, quantitative analysis of acoustics data and vertical migration models. The Theme Section thus represents a step forward towards better understanding long-term zooplankton time series, mysid omnivory, and the mysid ecological role in lake food webs.
\end{abstract}

KEY WORDS: Mysis relicta $\cdot$ Mysis diluviana $\cdot$ Zooplankton $\cdot$ Lakes $\cdot$ Food web

Mysids, or opossum shrimps, are members of the mostly marine order Mysidacea. There are some 30 species occurring in freshwater lakes and rivers, and the group has a worldwide distribution. Of these species, members of the Mysis relicta species complex have received the greatest attention because of their high abundance in some lakes (reported densities $>1000$ ind $\mathrm{m}^{-2}$ ), their importance as a food source for fishes, and their sometimes large effect on food web dynamics. The Mysis relicta species complex consists of 
4 species, 1 in North America (M. diluviana) and 3 in Eurasia (M. relicta, M. segerstralei, M. salemaai) (Audzijonyte \& Väinolä 2005). The complex is a glacial relict with circumpolar distribution in deep, cold lakes of the Northern Hemisphere. The biomass of mysids can exceed that of planktivorous fishes, with which they compete for zooplankton prey (Gal et al. 2006). Their potential effect on food webs was not fully appreciated until they were introduced into new lake habitats in an attempt to promote fish growth. Mysids often had strong negative effects on zooplankton and their introduction led to decreases in some of the fish species they were supposed to enhance (Lasenby et al. 1986, Nesler \& Bergersen 1991). Effects can cascade through ecosystem food webs to top predators such as bears and eagles (Spencer et al. 1991).

Mysid growth rate is a key component in calculating productivity of the mysid population and mysid consumption of various prey items (Johannsson et al. 2003), which are needed for inferences on the role of mysids in the food web. Growth rates vary widely, and are highest in highly productive lakes. Growth rates range from $0.2 \mathrm{~mm} \mathrm{mo}^{-1}$ in Lake Tahoe to $1.5 \mathrm{~mm} \mathrm{mo}^{-1}$ in mesotrophic lakes (review in Rudstam 2009), but they are difficult to measure in situ, especially when generations overlap. Johannsson et al. (2008) used nucleic acids and protein ratios as indicators of mysid growth and condition in laboratory experiments. Johannsson et al. (2009, this Theme Section) use this method to investigate inter-annual and spatial growth rate differences in Lake Ontario. The indices demonstrate differences in condition and growth rate, and suggest that certain essential fatty acids may be limiting in Lake Ontario.

Mysis spp. perform diel migrations at dusk and dawn from their daytime refuge in dark, deep water to the meta- or epilimnion, where they feed on zooplankton and algae. These migrations can be over $100 \mathrm{~m}$ and are limited by temperatures above 12 to $16^{\circ} \mathrm{C}$ and light levels above $10^{-4}$ lux, i.e. light levels that limit fish visual feeding. Boscarino et al. (2009a, this Theme Section) show that the actual distributions, not just the mean depth, can be predicted from the response of mysids to these variables in the laboratory (Boscarino et al. 2007, 2009b). Including the distribution of mysid prey and predators did not improve the predicting ability of the models. Because most of the interactions between mysids and their prey and predators likely occur at the edges of their vertical distributions, a better understanding of the whole distribution, not only the mean depth, is essential for adding a spatial dimension and more realism to predator-prey models. Diel vertical migrations are common in zooplankton (DeMeester 2009), and the approach by Boscarino et al. should also be useful for understanding the distribution of other migrating organisms.
Mysids are omnivores and capable of both filter-feeding and raptorial feeding. Mysids also feed on benthic prey, detritus and sediment during the day (Van DuynHenderson \& Lasenby 1986). Diets of mysids can vary greatly between neighboring lakes (Nordin et al. 2008). Whall \& Lasenby (2009, this Theme Section) examined the trophic role of Mysis diluviana in 2 neighboring lakes, one in which the introduction of mysids was associated with the collapse of kokanee salmon Oncorhynchus nerka (Okanagan Lake), and the other, in which it was not (Kalamalka Lake). They predicted that zooplankton would form a greater proportion of the diet of mysids in Okanagan Lake, where they were expected to compete more strongly with kokanee for zooplankton prey. However, comparison of mysid diets and clearance rates together with stable isotope signatures suggested that this was not the case. The study by Whall \& Lasenby (2009) shows how these different techniques can be combined to investigate mysid prey choice. The reason for the different food web effects in the 2 lakes, however, remains unknown.

Mysids were introduced in 1949 to Kootenay Lake, $\mathrm{BC}$, Canada, and are thought to be responsible for a large increase in growth rate of kokanee salmon and the spectacular fishery that developed after the introduction. After this reported success, mysids were introduced to many lakes and reservoirs in North America and Scandinavia to increase fish growth and production. However, results were not often those intended, as mysid predation caused declines in cladocerans, in particular in Daphnia. Koksvik et al. (2009, this Theme Section) show that an initial decline in cladocerans can be a transitory phenomenon. In Lake Lille Jonsvatn, the cladocerans returned after a period of $11 \mathrm{yr}$ with depressed Daphnia abundance. Koksvik et al. (2009) think that this may be due to increased water clarity, which limits mysid migration into shallower water and provides a refuge for cladocerans in the epilimnion. This study highlights the importance of longterm studies.

The contributions to this Theme Section represent the state of the art in mysid ecology. The papers are based on a symposium on mysid biology organized by Lars Rudstam, Ora Johannsson and Michael Arts at the International Society of Limnology meeting in Montreal in 2007. The mysid symposium represented an update of similar symposia held in the 1980s and 1990s (Morgan 1982, Nesler \& Bergersen 1991). The contributions to the present Theme Section include the use of techniques that were not available 20 years ago, such as DNA:RNA:protein ratios, fatty acids and stable isotopes as growth indicators, as well as quantitative analysis of acoustics data and vertical migration models, and thus represent a step forward towards better understanding the ecology of mysids in freshwater systems. 


\section{LITERATURE CITED}

Audzijonyte A, Väinolä R (2005) Diversity and distributions of circumpolar fresh- and brackish-water Mysis (Crustacea: Mysida): descriptions of $M$. relicta Lovén, 1862, M. salemaai n. sp., M. segerstralei n. sp. and $M$. diluviana n. sp., based on molecular and morphological characters. Hydrobiologia 544:89-141

Boscarino BT, Rudstam LG, Mata S, Gal G, Johannsson OE, Mills EL (2007) The effects of temperature and predatorprey interactions on the migration behavior and vertical distribution of Mysis relicta. Limnol Oceanogr 52: $1599-1613$

Boscarino BT, Rudstam LG, Eillenberger JJ, O'Gorman R (2009a) Importance of light, temperature, zooplankton and fish in predicting the nighttime vertical distribution of Mysis diluviana. Aquat Biol 5:263-279

Boscarino BT, Rudstam LG, Loew E, Mills EL (2009b) Behavioral responses of the opossum shrimp, Mysis relicta, to different intensities of light and light-temperature combinations. Can J Fish Aquat Sci 66:101-113

DeMeester L (2009) Diel vertical migration. In: Likens GE (ed) Encylopedia of inland waters. Elsevier, Oxford, p 651-658

Gal G, Rudstam LG, Mills EL, Lantry JR, Johannsson OE, Greene CH (2006) Mysid and fish zooplanktivory in Lake Ontario: quantification of direct and indirect effects. Can J Fish Aquat Sci 63:2734-2747

Johannsson OE, Rudstam LG, Gal G, Mills EL (2003) Mysis relicta in Lake Ontario: population dynamics, trophic linkages and further questions. In: Munawar M (ed) State of Lake Ontario (SOLO) - past, present and future. Backhuys Publishers, Leiden, p 257-287

Johannsson OE, Bowen KL, Wood CM, Smith R, Chu C, Rudstam LG, Boscarino B (2008) Relating nucleic acid and protein indices to growth in Mysis relicta: ration, cycling temperature, and metabolism. Aquat Biol 4:33-46

Johannsson OE, Bowen KL, Arts MT, Smith RW (2009) Field assessment of condition indices (nucleic acid and protein) in Mysis diluviana. Aquat Biol 5:249-262

Koksvik JI, Reinertsen H, Koksvik J (2009) Plankton development in Lake Jonsvatn, Norway, after introduction of Mysis relicta: a long-term study. Aquat Biol 5:293-304

Lasenby DC, Northcote TG, Fürst M (1986) Theory, practice, and effects of Mysis relicta introductions to North American and Scandinavian lakes. Can J Fish Aquat Sci 43: $1277-1284$

Morgan MD (ed)(1982) Ecology of Mysidacea. Hydrobiologia 93:1-222

Nesler TP, Bergersen EP (1991) Mysids in fisheries: hard lessons from headlong introductions. Am Fish Soc Symp 9: $1-4$

Nordin LJ, Arts MT, Johannsson OE, Taylor WD (2008) An evaluation of the diet of Mysis relicta using gut contents and fatty acid profiles in lakes with and without the invader Bythotrephes longimanus (Onychopoda, Cercopagidae). Aquat Ecol 42:421-436

Rudstam LG (2009) Other zooplankton. In: Likens GE (ed) Encyclopedia of inland waters. Elsevier, Oxford, pp 667-677

Spencer CM, McClelland BR, Stanford JA (1991) Shrimp stocking, salmon collapse, and bald eagle displacement: cascading interaction in a food web of a large aquatic ecosystem. Bioscience 41:14-21

Van Duyn-Henderson JA, Lasenby DC (1986) Zinc and cadmium transport by the vertically migrating opossum shrimp, Mysis relicta. Can J Fish Aquat Sci 43:1726-1732

Whall JD, Lasenby DC (2009) Differences in the trophic role of Mysis diluviana in two intermontane lakes. Aquat Biol 5:281-292 